\title{
Corrigendum: Clostridium chauvoei, an Evolutionary Dead-End Pathogen
}

\section{Lorenz Rychener ${ }^{1+}$, Saria In-Albon ${ }^{1 \dagger}$, Steven P. Djordjevic ${ }^{2}$, Piklu Roy Chowdhury ${ }^{2}$, Pamela Nicholson ${ }^{1}$, Rosangela E. Ziech ${ }^{3}$, Agueda C. de Vargas ${ }^{3}$, Joachim Frey ${ }^{1 *}$ and Laurent Falquet ${ }^{4}$}

\begin{abstract}
${ }^{1}$ Institute of Veterinary Bacteriology, Vetsuisse Faculty, University of Bern, Bern, Switzerland, ${ }^{2}$ The iThree Institute, University of Technology Sydney, Ultimo, NSW, Australia, ${ }^{3}$ Department of Preventive Veterinary Medicine, Federal University of Santa Maria, Santa Maria, Brazil, ${ }^{4}$ Department of Biology, Swiss Institute of Bioinformatics, University of Fribourg, Fribourg, Switzerland
\end{abstract}

Keywords: Clostridium chauvoei, CRISPR, virulence genes, flagellin genes, blackleg, dead-end evolution

\section{A corrigendum on}

\section{OPEN ACCESS}

Approved by:

Microbiology Editorial Office,

Frontiers, Switzerland

${ }^{*}$ Correspondence: Joachim Frey joachim.frey@vetsuisse.unibe.ch

${ }^{\dagger}$ Shared first authorship.

Specialty section: This article was submitted to Infectious Diseases,

a section of the journal

Frontiers in Microbiology

Received: 21 February 2018 Accepted: 22 February 2018 Published: 06 March 2018

Citation:

Rychener L, In-Albon S, Djordjevic SP

Chowdhury PR, Nicholson P, Ziech RE, de Vargas AC, Frey $J$ and

Falquet L (2018) Corrigendum: Clostridium chauvoei, an Evolutionary Dead-End Pathogen.

Front. Microbiol. 9:421. doi: 10.3389/fmicb.2018.00421

\section{Clostridium chauvoei, an Evolutionary Dead-End Pathogen}

by Rychener, L., InAlbon, S., Djordjevic, S. P., Chowdhury, P. R., Ziech, R. E., de Vargas, A. C., et al. (2017). Front. Microbiol. 8:1054. doi: 10.3389/fmicb.2017.01054

In the published article, Pamela Nicholson was not included as an author. In addition, author names were incorrectly spelled as Saria InAlbon and Piklu R. Chowdhury. The correct spellings are Saria In-Albon and Piklu Roy Chowdhury.

The authors apologize for these errors and state that they do not affect the scientific conclusions of the article in any way.

The original article has been updated.

\section{AUTHOR CONTRIBUTIONS}

JF, LF, and SD conceived the study and performed the genomic analyses. PN performed strain isolations and DNA preparations. Bioinformatic analyses was made by SI-A and LR. PC established the phylogenic relationship using by PhyloSift. RZ and AdV provided strains and metadata from strains of Brazil.

Conflict of Interest Statement: The authors declare that the research was conducted in the absence of any commercial or financial relationships that could be construed as a potential conflict of interest.

Copyright (c) 2018 Rychener, In-Albon, Djordjevic, Chowdhury, Nicholson, Ziech, de Vargas, Frey and Falquet. This is an openaccess article distributed under the terms of the Creative Commons Attribution License (CC BY). The use, distribution or reproduction in other forums is permitted, provided the original author(s) and the copyright owner are credited and that the original publication in this journal is cited, in accordance with accepted academic practice. No use, distribution or reproduction is permitted which does not comply with these terms. 